\title{
WHAT EFFECT DO TIME CONSTRAINTS HAVE ON THE AGE OF RETIREMENT?
}

Leora Friedberg, Wei Sun, and Anthony Webb

CRR WP 2008-17

Released: December 2008

Date Submitted: October 2008

\author{
Center for Retirement Research at Boston College \\ Hovey House \\ 140 Commonwealth Avenue \\ Chestnut Hill, MA 02467 \\ Tel: 617-552-1762 Fax: 617-552-0191
}

The research reported herein was pursuant to a grant from the U.S. Social Security Administration (SSA) funded as part of the Retirement Research Consortium (RRC). The findings and conclusions expressed are solely those of the authors and do not represent the views of SSA, any agency of the Federal Government, the RRC, Boston College, or the University of Virginia.

(c) 2008, by Leora Friedberg, Wei Sun, and Anthony Webb. All rights reserved. Short sections of text, not to exceed two paragraphs, may be quoted without explicit permission provided that full credit, including (C) notice, is given to the source. 


\title{
About the Center for Retirement Research
}

The Center for Retirement Research at Boston College, part of a consortium that includes parallel centers at the University of Michigan and the National Bureau of Economic Research, was established in 1998 through a grant from the Social Security

Administration. The Center's mission is to produce first-class research and forge a strong link between the academic community and decision makers in the public and private sectors around an issue of critical importance to the nation's future. To achieve this mission, the Center sponsors a wide variety of research projects, transmits new findings to a broad audience, trains new scholars, and broadens access to valuable data sources.

\author{
Center for Retirement Research at Boston College \\ Hovey House \\ 140 Commonwealth Avenue \\ Chestnut Hill, MA 02467 \\ phone: 617-552-1762 fax: 617-552-0191 \\ e-mail: crr@bc.edu \\ www.bc.edu/crr
}

Affiliated Institutions:

The Brookings Institution

Massachusetts Institute of Technology

Syracuse University

Urban Institute 


\begin{abstract}
Work affects both the time available for non-market activities and the times at which those activities are performed - and therefore work-induced constraints on time use may influence retirement decisions. We analyze these effects by combining new data from the American Time Use Survey with information on retirement in the Health and Retirement Study.

We find that the propensity to engage in three types of non-work activities - household production, leisure, and tertiary activities (eating, sleeping, grooming) - are substantially altered by work. Moreover, the ways in which the timing of these activities are distorted differ across ten different job types (industry-occupation combinations) that we examine in the ATUS. We use the resulting measures of time distortions as control variables in multinomial logit retirement models that we estimate in the HRS. Older workers in jobs with greater distortions to the quantity and timing of leisure activities have an increased propensity to leave those jobs, either for new jobs or for retirement. On the other hand, workers in jobs with greater distortions to household production have a reduced propensity to leave their jobs, and distortions to tertiary activities raise the propensity to take new jobs but reduce the propensity to retire.
\end{abstract}




\section{Introduction}

One potential solution to inadequate retirement saving, and a likely consequence of increasing life spans, is for workers to delay retirement. Time constraints may affect individuals’ ability and willingness to extend their working lives. Work clearly affects both the amount of time available for non-market activities and the times at which those activities can be performed (Hamermesh and Donald, 2007). These constraints may be particularly severe for low-income workers who have relatively fixed work schedules and who may find it unprofitable to substitute market purchases for the non-market activity. They may also disproportionately affect women, who spend more time than men on care giving. The effect on labor force participation may be disproportionate to the time spent on the non-market activity if that activity (for example, cooking lunch for another household member) must be performed at a particular time, and is not one for which a market purchase can be readily substituted.

Yet, traditional data sets report little information on non-work time. For example, the extraordinarily rich data on income and assets in the Health and Retirement Study has facilitated the estimation of detailed retirement models that focus on financial resources. However, the HRS provides little information indicating how financial resources are converted into utility flows from either leisure or consumption. Other data sets, though they do not allow estimation of retirement models with the same level of financial detail, demonstrate that the leisure and consumption opportunities of individuals are intimately tied to both the timing of retirement and the activities of individuals during retirement (Bernheim, Skinner, and Weinberg 2001, Aguiar and Hurst 2005, 2008).

We seek to fill in this gap by combining new data from the American Time Use Survey (ATUS) with information on retirement transitions observed in the HRS. Few others have begun to use this new data, which began to be collected in 2003, to analyze retirement (Hamermesh and Donald 2007, Aguiar and Hurst 2005). The ATUS provides a snapshot showing how individuals spend their time, minute-by-minute and activity-by-activity, on a particular day. This makes it possible to compare the non-work activities - volunteering, taking classes, engaging in physical activity, cooking, cleaning, shopping, caring for family members, socializing, watching TV, and so on - of workers and retirees, and importantly, the timing of those activities. 
Hamermesh and Donald emphasize that work distorts the timing of leisure, household production, and personal activities like sleep. We investigate the extent to which older workers in jobs that involve greater distortions to daily time use will retire sooner, all else given, as they will experience greater utility gains from eliminating these distortions to time use patterns. We adapt the methodology of Hamermesh and Donald to measure these distortions for typical workers in the ATUS, distinguished by industry and occupation. We then include the measures of these distortions to daily activities as controls when we estimate multinomial logits to explain job transitions for aging workers in the HRS. The multinomial logit approach recognizes the richness of retirement transitions while maintaining a parsimonious and flexible estimation approach (Friedberg, Owyang, and Webb 2008).

Thus, our method exploits the advantages of two data sets, each of which provides rich information on some aspects of work but not others. The American Time Use Survey provides rich time use data for a large cross-section of individuals, but, lacking a substantive panel, the ATUS is not well suited for analyzing the timing of retirement. For this purpose, we use the Health and Retirement Study, which provides us information about high-frequency retirement transitions observed over a long period of time but has little information about time use. ${ }^{2}$

In Section II, we will analyze how work alters the timing of non-work activity for prime-age workers in the ATUS, grouped by industry and occupation. In Section III, we will match these job-specific measures to the HRS sample of older workers and use them to estimate the impact of work-related time constraints on retirement.

\section{MEASURING TIME CONSTRAINTS ASSOCIATED WITH WORK}

As the largely cross-sectional nature of the ATUS does not allow us to follow workers into retirement, we use the ATUS to measure how work alters the time spent on and timing of nonwork activities. We focus on a large sample of prime-age workers and group them by industry

\footnotetext{
${ }^{2}$ While the HRS has recently added both time use and expenditure information through the Consumption and Activities Mail Survey (CAMS), the CAMS has only been collected for a subset of HRS respondents via pencil and paper surveys mailed out in 2001, 2003, and 2005. Hurd and Rohwedder (2007) found that average time use patterns looked similar in the CAMS and ATUS, but the distributions of time use looked quite different. Also, the CAMS cannot be used to analyze how work alters the timing of activities, as it simply asks how many hours were spent on various activities in the last week or month.
} 
and occupation to measure these job-related constraints. After that, we will analyze how jobrelated changes to non-work time use influences retirement patterns in the HRS.

\section{A. The American Time Use Survey}

The ATUS is the first large, nationally representative, repeated survey of time use by Americans. Respondents are asked by telephone to relate their time use during the previous day. This results in information on the nature of each activity, and, importantly, when the activity took place, enabling us to investigate whether the timing of non-market activities influences an individual's propensity to work.

The ATUS consists of repeated cross-sections, with data available from 2003 through 2007. The response rate in 2003 was 57\%, yielding a sample of 20,720 respondents; subsequent samples were reduced by about $40 \%$ to trim costs. According to the User's Guide (2006, p.10), “The primary reason for non-response is that the designated persons are tired from participating in the CPS survey.” Of obvious concern is that the busier respondents are, the less willing they are to take time to respond to the ATUS. Evidence that we present later suggests that this does not generate systematic bias in our results. Abraham et al (2006) found that observed characteristics correlated with busyness - like usual weekly hours of work and presence of children - had little effect on response rates.

We pool data from the five years of the ATUS, yielding a total sample size of 72,922. From this group, we exclude 895 individuals who said they were working but did not provide industry and occupation codes. Then, we eliminate individuals aged 60 and over, as people who retire late are a selected sample that is likely to have different time use patterns while working than those who retire early. These exclusions reduce the sample size to 55,318. This includes both weekdays and weekends (with each comprising roughly $50 \%$ of the sample), and we consider changes to both together, since working alters time use patterns on weekends as well as weekdays, as well as changes to weekday and weekend time use separately.

\section{B. Methodology}

Following Hamermesh and Donald (Appendix A), we group non-work activities into three categories: leisure $(\mathrm{L})$, home production $(\mathrm{H})$, and tertiary activities $(\mathrm{T})$. Home production 
includes housework and care of children and others. ${ }^{3}$ Leisure consists of talking with others, reading, watching television, participating in physical activity, etc. Tertiary activities include sleeping, eating and drinking, and personal care activities, such as bathing and grooming; these are activities that must be done for oneself and not by others, and thus cannot be purchased.

We run regressions explaining the propensity to engage in these activities throughout the day as a function of whether the individual works and average minutes of work, conditional on working. The goal is to see how the incidence and intensity of work alter the scheduling of other activities throughout the day; in Hamermesh and Donald, these are meant to capture the "fixed" and "marginal” time costs of work upon other activities. We add additional information which they do not consider by interacting both variables with the worker's industry and occupation. In this way, we aim to exploit the variation in non-work activities of workers across different industries and occupations.

The regressions take the form of weighted probits of the probability that an individual engages in either $\mathrm{L}, \mathrm{H}$, or $\mathrm{T}$ at every 15-minute interval, defined at the midpoint of each quarter hour of the day. Sample weights are used so that the results are nationally representative. We include three types of control variables:

- Variables representing the "fixed cost" of work. We control for whether an individual is working, and if so in what industry and occupation. We interact four industry categories (construction/mining/ agriculture, manufacturing, professional services, non-professional services) with three occupation categories (skilled, semi-skilled, and unskilled), except that all workers in the first industry category are grouped together for reasons of sample size. ${ }^{4}$ This $^{4}$ results in 10 industry-occupation categories. The coefficients on these industry-occupation dummies measure the effect of any work in a particular type of job (relative to a base case of not working) on the propensity of the individual to alter their activity during each quarter hour. We further interact a work dummy with an indicator for whether household income is greater than

\footnotetext{
${ }^{3}$ Based on the 2003 and 2004 ATUS lexicons, activities are allocated as follows: market work (codes 0501-0599, 1705), household production (0201-0299, 0301-0499, 0701-1099, 1501-1599, 1603-1608, 1702-1704, 1707-1710, 1715), tertiary activities (0101-0199, 1101-1199, 1701, 1711, and leisure (0601-0699, 1201-1499, 1601-1602, 1706, 1712-1714). Adjustments were made to coding in later years as the lexicon changed.

${ }^{4}$ The HRS provides 13 industry and 17 occupation codes, derived from the 2000 Census industry and occupation codes. Based on previous literature, we group industry codes 1-2 as agriculture/construction/mining, 3-5 as manufacturing, 6-11 as professional and 12-13 as nonprofessional. We group occupation codes 1-2 (managerial, professional) as skilled, 3-4 (clerical, sales) as semiskilled, and all others as unskilled. This necessitates adapting the coding in the 2002 ATUS, which uses 1990 industry and occupation codes, to match this structure.
} 
$\$ 50,000$, as high income households may have different opportunities to substitute between the purchase and production of household services.

- Variables representing the "marginal cost" of work. We also control for the 10 job types described above interacted with average minutes of daily work for that job type, as observed in the same ATUS sample. This captures the effect of more or less average minutes of work on the timing of non-work activities.

- Demographic variables. We include other control variables to capture systematic differences in time use on the basis of gender, age and age squared, race and Hispanic ethnicity, marital status, and the presence of children of various ages $(0-2,3-5,6-13,14-17)$ in the household.

As an alternative to including gender and marital status controls, we also partitioned the sample and ran the regressions separately for each of four subsamples that are likely to experience differences in time use and in the importance of time constraints; these subsamples are married males $(13,859)$, married females $(16,600)$, single males $(10,756)$ and single females $(14,103)$. Lastly, while there are 96 15-minute intervals during each day, we only used 70 of them, from 6:00 AM until 11:30 PM. There was too little variation in activities undertaken during the middle of the night for people in different types of job to obtain useful results.

\section{Results}

As a result of this, we obtain probit coefficients for three activity types (L, H, T) for 70 quarter hours for 5 demographic samples (everyone, married and single men and women) for various times of the day and week (every day, weekdays, weekends). We find that the effect of work on the timing of non-work activities is jointly significantly different across the 10 job types we consider.

Our next step is to construct a measure of the "work constraint effect" for each of the job types in which we are interested. We begin with non-workers as a base case and use the probit coefficients to predict the probability of each activity in a given quarter hour; to do this, we set all demographic variables to their sample mean and all interactions involving work and job type

described above to zero. Thus, we obtain results like $\hat{p}_{0}^{H, 0600}$, the predicted probability that a non-worker engages in home production at the midpoint of the 6:00-6:15 AM interval. Then we 
switch the job category to, say, an unskilled worker in the manufacturing sector, using the estimated probit coefficients on both the work and work minutes interactions with the unskilled manufacturing job dummy to obtain $\hat{p}_{M F G, U N}^{H, 060}$. We take the difference between the two predicted probabilities as a measure of how being an unskilled manufacturing worker alters the probability of doing home production between 6:00-6:15 AM. Similar calculations for all 70 15-minute intervals yields the full set of differences in the probability of undertaking each type of non-work activity in each interval for each job type.

We show a few of these graphically to give a sense of the results. Figure 1 shows how working in a skilled occupation in the professional services category (as opposed to not working) alters the probability of engaging in home production during each 15-minute interval between 6:00 AM and 11:30 PM. Many of these effects are significantly different from zero - so the propensity to engage in home production is significantly changed. Specifically, work raises the probability of engaging in home production by a little less than percentage points during the first couple hours after 6:00 AM and by 5-10 percentage points from mid-afternoon through early evening. Meanwhile, the effect of the average minutes worked in this job category (shown underneath the above figure) is to reduce home production in the middle of the day, from midmorning to early afternoon. The shift in the time pattern of home production is similar for other job types, while the particular magnitudes differ. For example, among unskilled workers in professional services, the change in the early morning and evening propensity to do home production is closer to zero, but the change in the late afternoon is greater.

Figures 2 and 3 show graphs reflecting how tertiary activities and leisure are altered among people in the same occupations. The distortions to home production are a little greater in magnitude than the distortions to leisure and to tertiary activities. Working at all (as shown in the top figures) tends to shift leisure towards the early morning and late evening intervals, while average minutes of work tend to have a greater effect in depressing leisure activities during the middle of the day. Working at all similarly raises the likelihood of engaging in tertiary activities at certain times - notably, raising the probability of eating at certain times (the middle of the day, the end of the typical work day) and reducing the likelihood of sleeping in the late hours before 11:30 PM. Greater average minutes of work also reduce the likelihood of being asleep early in the morning. 
Our last step is to develop a measure that captures the overall change in non-work time during the day. To do this, we sum the absolute value of the differences in the predicted probabilities for each job type (like $\hat{p}_{M F G, U N}^{H, 0600}$ ) to obtain constra int ${ }_{M F G, U N}^{H}=\sum_{t=0600}^{2330} \hat{p}_{M F G, U N}^{H, t}$, indicating by how much the propensity to engage in home production through the day is altered by being, in this case, an unskilled manufacturing worker. We similarly compute this measure for leisure and tertiary activities to obtain a set of variables constra int ${ }_{k}^{a}$ for the three activities $a$ $=\{L, H, T\}$ and the 10 industry-occupation groups $k$. We also compute constra int ${ }_{k}$ by adding across all three activities to arrive at a total "work constraint" measure for each industryoccupation job type.

We will use these measures of time constraints as control variables in retirement models estimated using the HRS. The resulting measures are shown in Table 1. Thus, in the row for all skilled workers in the professional services sector, the value of 5.30 indicates the sum of the change in predicted probabilities, in absolute value, of engaging in household production between 6:00 AM-11:30 PM. The average change in the predicted probabilities for any one of the 70 time intervals is thus $5.30 / 70=0.076$, or 7.6 percentage points (which may be positive in some intervals and negative in others). For the same job type, this value is 2.72 for tertiary activities and 3.70 for leisure, so work in this category alters the propensity to engage in nonwork activities in an average time interval by almost $(5.30+2.72+3.70) / 70=11.73 / 70=0.168$, or about 16.8 percentage points. For the same job type, married men have the highest value of the job-imposed time constraint, at 14.58, while single women have the lowest value, at 12.22. Among job types, the highest value of the time constraint is 17.36, for agriculture/construction/ mining, and the lowest is 7.45, for unskilled workers in nonprofessional services.

Table 2 shows that the time constraints are somewhat higher on weekdays. Interestingly, on weekdays they differ both during typical work hours and at other times. The time constraints also differ for workers on weekends, even though most workers are not working then.

\section{ESTIMATING THE IMPACT OF TIME CONSTRAINTS ON RETIREMENT}

After measuring how particular jobs constrain non-work activities in the ATUS, we can now match those measures to the jobs of aging workers in the HRS. We include the job-related 
measures in a retirement model while controlling for job type, so that we can test whether they influence the path of full or phased retirement.

\section{A. The Health and Retirement Study}

The HRS is a detailed longitudinal survey of over 7,600 households with a member born between 1931 and 1941. The HRS began in 1992 and surveys people every two years. We use data from the first seven waves through $2004 .^{5}$ The HRS asks about the precise timing of job transitions. It also provides enormous detail about covariates which are important in explaining retirement - like job characteristics, health, marital status, and assets. We will use industry and occupation to match individuals to information about time constraints associated with jobs.

The HRS is intended to be nationally representative, subject to oversampling of minorities and Florida residents. ${ }^{6}$ We select our sample as follows. Beginning with 12,652 individuals in the 1992 HRS, we keep 11,314 of them who also appear in Wave 2, so we observe at least one transition for each. We drop 272 under age 50 or above age 69 in 1992, leaving 11,042. We drop a further 1,069 who lived outside a metropolitan area and 8 whose work status was unknown, leaving 9,965 whose labor force transitions were observed for periods varying from roughly two years, if they left the survey after 1994, to twelve years, if they remained until 2004.

We use the recall data on job transitions to convert person-wave observations into 86,145 person-year observations, with each individual's status measured from one birthday to the next. These person-year observations include information on whether the person was working for the same employer, working for a different employer, or not working at the start and end of the period. $^{7}$ We then exclude observations where the individual is not working at the beginning of a period, leaving 33,735 observations. Lastly, we drop observations without information on industry, occupation, or self-employment status, resulting in 33,655 observations for the overall sample. For the four subsamples, we have 13,301 married males, 12,346 married females, 1,799 single males, and 6,209 single females.

\footnotetext{
${ }^{5}$ Where possible, we make use of the RAND HRS data file, a cleaned version of the original. We have not incorporated cohorts entering into the HRS in 1998 or 2004.

${ }^{6}$ We find that after inclusion of sample weights, the sample is indeed broadly nationally representative.

${ }^{7}$ In contrast to our annual approach, Gustman and Steinmeier (2001) tracked individuals by wave (over two years), which reduces precision in predicting retirement since many important milestones, such as attaining age 62 or 65 , or one's normal retirement age, occur on the individual's birthday.
} 
To give an idea of how the sample moves into transitions, we note that, between turning 55 and turning 56, 88.2\% of the sample (consisting of people who are in a job at 55) stays in the same job, while $7.0 \%$ take another job, and $4.8 \%$ retire. Staying in the job occurs with almost the same frequency at age $60,86.5 \%$, and declines to $84.7 \%$ at age 61 and $77.7 \%$ at age 62 . Exits to another job decline gradually as the sample ages, while exits to retirement rises to 8.5\% at age $60,11.7 \%$ at age 61 , and $16.7 \%$ at age 62 .

\section{B. Methodology}

The emphasis in the literature on the heterogeneity in retirement transitions - with some moving from full-time work to full retirement, but many others taking "bridge jobs" along the way explains our multichotomous approach (Ruhm 1990, Gustman and Steinmeier 1986). This approach is richer than common specifications that pick a single binary definition of retirement (leaving a career job, describing oneself as retired, working zero hours, etc). Relative to the frontier of the structural retirement literature (e.g., Rust and Phelan 1997, Gustman and Steinmeier 2005, French 2005), we do not specify underlying preferences, model features of job outcomes that are not chosen, or capture the full dynamics involved in the evolution of retirement benefits. Accounting for these issues carefully would require making functional form assumptions that tend to have little clear empirical justification.

Thus, we will seek to explain the probability of observing outcome $y_{n t k}=\{$ stay in job, leave for another job, retire \} for each individual $n$ in each year $t$. Ignoring for now possible correlation of the error term across observations for the same individual, we can write $y_{n t k}=y_{i k}$. The probability that a particular $y_{i k}$ is observed, conditional on observables $x_{n t}$, can be expressed as

$$
\operatorname{Pr}\left[y_{i k}=j \mid x_{i}\right]=\frac{\exp \left(x_{i}^{\prime} \beta_{j}\right)}{1+\sum_{j=1}^{K} \exp \left(x_{i}^{\prime} \beta_{j}\right)}
$$

This specification will yield coefficient estimates for each covariate $x_{i}$ that are specific to each outcome $k$. As is usual in the multinomial formulation, those coefficients are identified for $K-1$ of the outcomes, relative to an arbitrarily chosen outcome as a base case. 
The results in these tables are presented in the form of relative risk ratios (RRR). The RRR is a transformation of the estimated logit coefficient and captures the marginal effect of the righthand side variable on the likelihood of a particular job transition occurring relative to the likelihood of the base outcome (staying in the job) occurring. If the RRR takes a value equal to one, then the right-hand side variable does not alter the likelihood of that particular job transition occurring relative to staying in the job. If the RRR takes a value that is smaller than one, then the variable reduces the likelihood of the job transition occurring relative to staying in the job by the percentage of RRR-1, and if the RRR takes a value greater than one, it raises the likelihood relative to staying in the job. The standard errors are transformed as well to correspond to the relative risk ratios and can be compared with RRR-1 using the critical values for z-statistics; so, if, upon computing RRR-1 and dividing by the transformed standard error reported in the table, one obtains a value that is roughly two, the corresponding RRR is statistically significant at roughly the $95 \%$ confidence level.

In our estimation, we control for the work constraints we measured above from the ATUS. In some cases, we control for the three activity-specific values constra int ${ }_{k}^{a}$, where $a$ represents leisure $\mathrm{L}$, home production $\mathrm{H}$, and tertiary activities $\mathrm{T}$, and in others for their sum constraint $_{k}$, as they are to some degree collinear. We also control to the extent possible for job type, so as to pick up other factors related to particular jobs or the types of people who work in particular jobs. The limitation is that we must drop not one but two of our 10 job type categories, as constraint ${ }_{k}$ does not vary within job type and so is a linear combination of job type. ${ }^{8}$ In accommodating this source of collinearity, we can identify the time-related constraints of job type, as long as these are not perfectly correlated with other unmeasured traits that vary by job type.

In order to reduce potential problems that may arise because we cannot control fully flexibly for effects of job type on retirement, we add controls for observable job characteristics reported by HRS respondents. People were asked whether there jobs required "lots of physical effort", "heavy lifting”, “stooping, kneeling, or crouching”, and "good eyesight”. We also control for whether a job involves responsibility over "pay and promotion decisions".

\footnotetext{
${ }^{8}$ We must drop additional job type dummies when including the three separate measures constra int $t_{k}^{a}$, for activities $a=\{L, H, T\}$.
} 
Lastly, we include a rich set of demographic and compensation-related variables that are available in the HRS: gender, race, education (3 categories), self-reported health (5 categories), single age dummies, financial wealth by quintile (which, though potentially endogenous, influences retirement but does not alter other estimated coefficients much when included), job tenure, plant size (6 categories), union membership, and the current wage. We also include information on employer-provided pensions. We use self-reported information on pension type (defined benefit, defined contribution, both, none) and an indicator for being older than the DB full retirement age. ${ }^{9}$

\section{Estimation Results}

Column 4.1 in Table 4 shows the multinomial logit results when we do not include any measure of work-related time constraints. The column on the left shows the relative risk ratios (RRR), reflecting how each covariate alters the likelihood of leaving one's beginning-of-the-year job for another job. The column on the right shows the RRRs for the likelihood of leaving one's job and retiring.

Column 4.2 adds the aggregate time constraint constraint $_{k}$ faced by people in industryoccupation group $k$. Here, we find that a higher value of this number - meaning more total distortions in daily non-work activities, compared to non-workers - raises the likelihood of switching jobs but not of retiring. Recall that the range of values that constraint $_{k}$ takes for the full sample is [7.45, 17.36]. Moreover, if a job altered the likelihood of engaging in non-work activities in each of the 70 time intervals we consider by 10 percentage points, then constraint $_{k}$ would take a value of $0.10 * 70=7$. As the RRR associated with constraint ${ }_{k}$ for transitions to a new job is 1.204 , then a value of 7 for constraint ${ }_{k}$ is associated with a $(1.204-1) * 7=143 \%$ increase in the likelihood of moving to a new job.

When we distinguish the impact of the separate measures of work-related constraints on different types of non-work activities, we find that distortions to leisure time lead to moves into both new jobs and retirement (though the latter is not statistically significant). Distortions to home production reduce the likelihood of leaving one's job. Distortions to tertiary activities lead

\footnotetext{
${ }^{9}$ While Gustman and Steinmeier (1999) showed that individuals report this information with substantial error, Chan and Stevens (2008) found that retirement responded more to one's beliefs about one's pension type, but also that, as people approached retirement, the accuracy of their information improved; therefore, it is reasonable to consider both measures. We have not as yet tried controlling for an individual's Social Security wealth and retirement incentives, as this involves the use of restricted data.
} 
to more new jobs but less retirement. Table 5 shows additional results, only reported for the time constraints, when we alter the measured time constraint or the demographic sample.

This effect falls short of statistical significance for the first outcome but is significant for the second. ${ }^{10}$ The variable constraint ${ }_{k}$ has a standard deviation of 3.05, and a one-standard deviation increase in the time constraint raises the likelihood of leaving one's job for retirement by $(1.0199-1) * 3.05=6.1 \%-$ a substantial jump. For married men (the largest subsample), the effect is even larger (with a log odds ratio of 1.0373), while for other groups the effect is not statistically significant. For married women, the log odds ratio is larger still but not statistically significant. It is not surprising that time constraints matter more for married people than for singles, as time spent together is one of the chief features of marriage. ${ }^{11}$

Next, we analyze time constraints as they relate to particular activities - leisure, home production, and tertiary activities - though collinearity is an issue. For the sample as a whole, distortions to tertiary activities significantly raise the likelihood of leaving one's job, whether to another job or to retirement; distortions to home production significantly reduce the likelihood of exiting to a new job but raise the likelihood of retiring; and distortions to leisure significant raise the likelihood of exiting to a new job but reduce the likelihood of retiring. Most of these estimates fall short of conventional levels of statistical significance, but often not by much.

\section{CONCLUSIONS}

Time constraints may affect individuals’ ability and willingness to extend their working lives. Work clearly affects both the amount of time available for non-market activities and the times at which those activities can be performed. Yet, traditional data sets report little information on non-work time. We seek to fill in this gap by combining new data from the American Time Use Survey with information on retirement transitions observed in the Health and Retirement Study. We measure distortions to non-work activities experienced in different types of jobs in the ATUS, and we investigate the extent to which older works in jobs that involve greater distortions to time use retire sooner.

\footnotetext{
10 As we have relatively little variation in our time constraints variable, which are defined for ten industryoccupation categories, a lack of statistical significance is a common theme in some of our results.

${ }^{11}$ It is also interesting that the results are greater for married men than for married women. With the emphasis on husbands' responsiveness, this may be consistent with evidence from Coile (200y) that married men time their retirement to their wives behavior, rather than vice versa.
} 
We find that the propensity to engage in three types of non-work activities - household production, leisure, and tertiary activities (eating, sleeping, grooming) - are substantially altered by work. Moreover, the ways in which the timing of these activities are distorted differ across ten different job types (industry-occupation combinations) that we examine in the ATUS. We use the resulting measures of time distortions as control variables in multinomial logit retirement models that we estimate in the HRS. Older workers in jobs with greater distortions to the quantity and timing of leisure activities have an increased propensity to leave those jobs, either for new jobs or for retirement. On the other hand, workers in jobs with greater distortions to household production have a reduced propensity to leave their jobs, and distortions to tertiary activities raise the propensity to take new jobs but reduce the propensity to retire.

Our research demonstrates that individuals' retirement hazard is responsive to the severity of their time use constraints. We propose extending the above analysis to consider the impact that plausible relaxations of time constraints - for example, through flexible working hours - might have on the average age of retirement. 


\section{REFERENCES}

Aguiar, Mark, and Erik Hurst. 2005. “Consumption vs. Expenditure.” Journal of Political Economy 113 (5), pp. 919-948.

Aguiar, Mark, and Erik Hurst. 2008. “Deconstructing Lifecycle Expenditure.” Manuscript, University of Chicago.

Bernheim, B. Douglas, Jonathan Skinner, and Steven Weinberg. 2001. "What Accounts for the Variation in Retirement Wealth among U.S. Households?” American Economic Review 91 (4), pp. 832-857.

Coile, Courtney, and Jonathan Gruber. "Future Social Security Entitlements and the Retirement Decision.” Review of Economics and Statistics 89 (2), pp. 234-246.

French, Eric. 2005. “The Effects of Health, Wealth, and Wages on Labor Supply and Retirement Behavior.” Review of Economic Studies 72 (2), pp. 395-427.

Friedberg, Leora, and Michael Owyang. 2002. "Explaining the Evolution of Pension Structure and Job Tenure.” Federal Reserve Bank of St. Louis Economics Working Paper 2002-022D.

Friedberg, Leora, Michael Owyang, and Anthony Webb. "Identifying Local Differences in Retirement Patterns.” Manuscript, Boston College Center for Retirement Research.

Friedberg, Leora, and Anthony Webb. 2005. "Retirement and the Evolution of Pension Structure.” Journal of Human Resources 40 (2), pp. 281-308.

Gustman, Alan, and Thomas Steinmeier. 1999. "What People Don't Know About Their Pensions and Social Security: An Analysis Using Linked Data from the Health and Retirement Study.” National Bureau of Economic Research Working Paper No. 7368.

Gustman, Alan, and Thomas Steinmeier. 2001. "Retirement and Wealth.” Social Security Bulletin 64 (2) 2001-2002, pp. 66-91.

Gustman, Alan, and Thomas Steinmeier. 2005. "The Social Security Early Retirement Age in a Structural Model of Retirement and Wealth.” Journal of Public Economics 89 (2-3), pp. 441463.

Hurd, Michael, and Susann Rohwedder. 2007. “Time-Use in the Older Population: Variation by Socio-economic Status and Health.” Manuscript, RAND Corporation.

Rust, John, and Christopher Phelan. 1997. "How Social Security and Medicare Affect Retirement Behavior in a World with Incomplete Markets.” Econometrica 65(4), pp. 781-832. 
Ruhm, Christopher. 1990. "Bridge Jobs and Partial Retirement." Journal of Labor Economics, 8 (4), pp. 482-501.

U.S. General Accounting Office. 2001. Older Workers: Demographic Trends Pose Challenges for Employers and Workers. General Accounting Office Report GAO 02-85. Washington, DC: US General Accounting Office. 


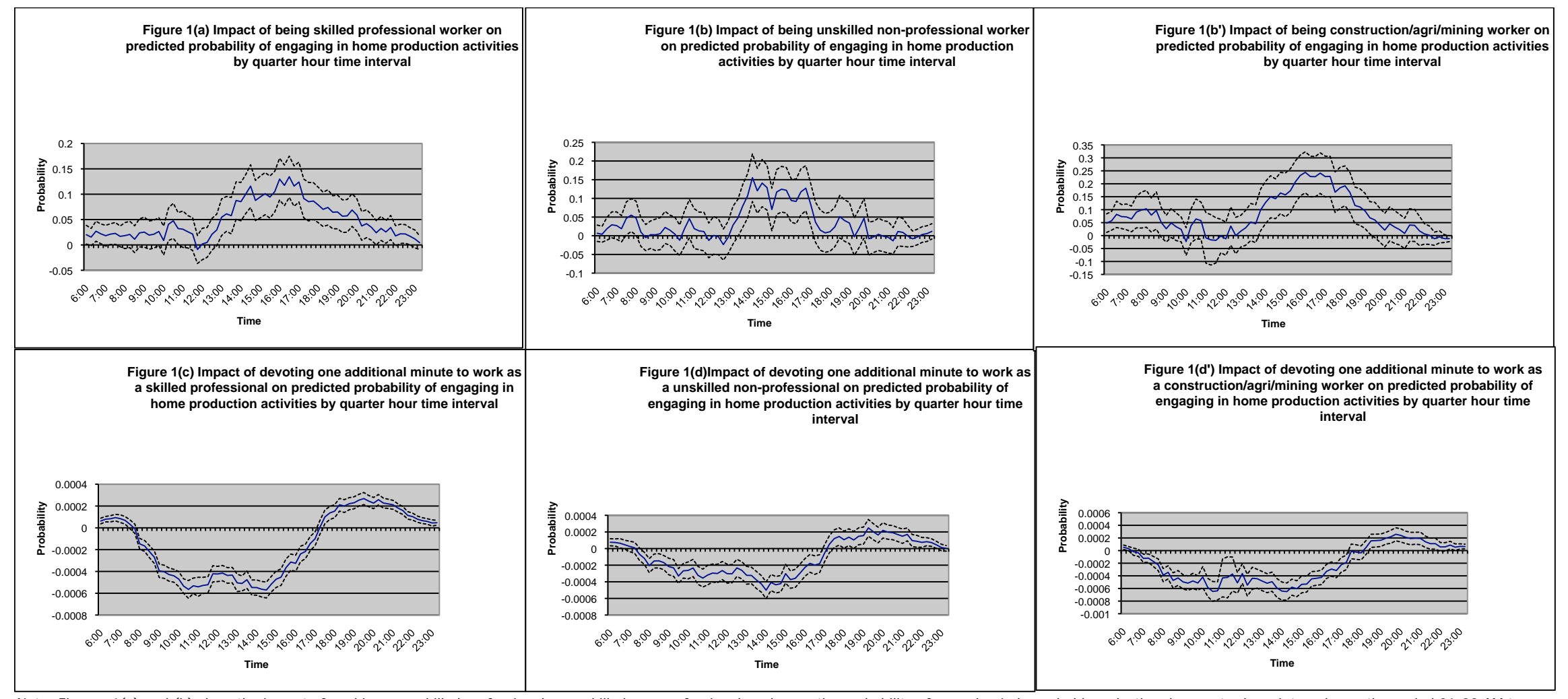

Note: Figures 1 (a) and (b) show the impact of working as a skilled professional or unskilled non-professional worker on the probability of engaging in household production, by quarter hour interval over the period $06: 00$ AM to 1:00 PM, relative to not working. Figures 1 (c) and 1 (d) show the impact on the probability of participation of an additional minute devoted to work in the above occupations. The solid line shows the point estimate, and the dotted lines the $95 \%$ confidence interval. 


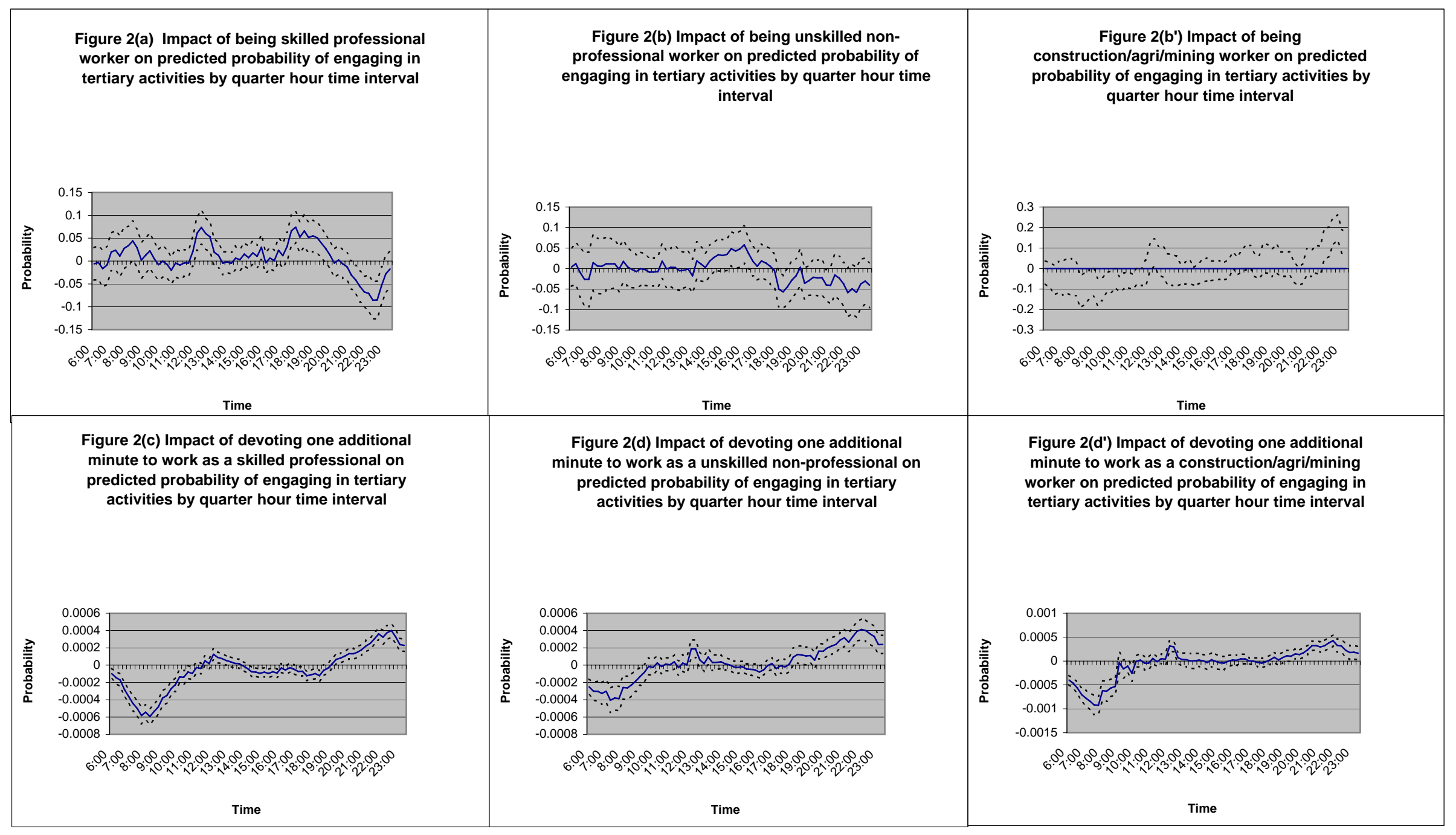




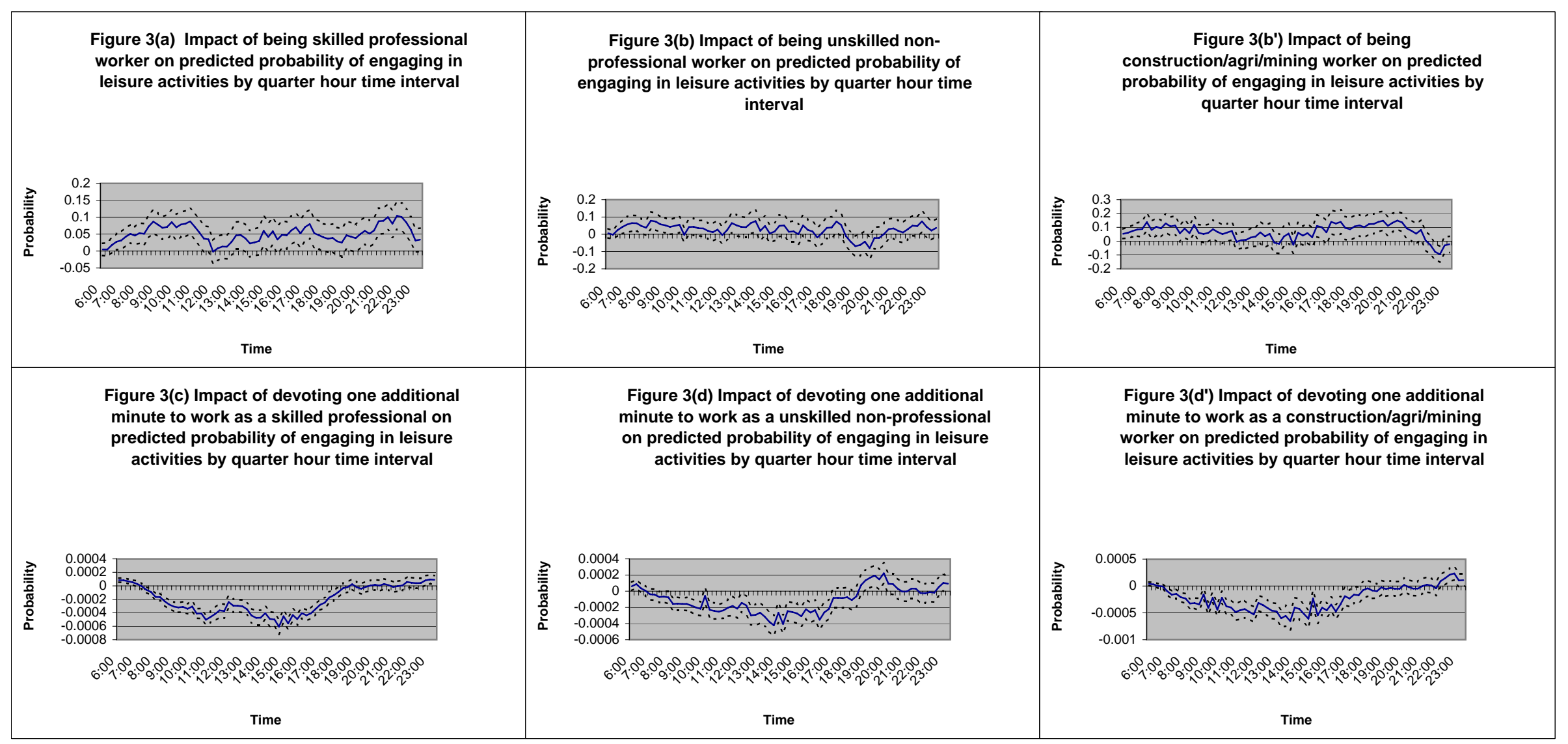


Table One: Impact of Industry and Occupation on Time Allocation - weekdays and weekends Effect of occupation on probability of particiapting in non-work activities, averaged over all quarter-hour period

$\begin{array}{lcccc}\text { Occupation } & \begin{array}{l}\text { All non-work } \\ \text { activities }\end{array} & \begin{array}{l}\text { Household } \\ \text { production }\end{array} & \begin{array}{l}\text { Tertiary } \\ \text { activities }\end{array} & \text { Leisure } \\ \text { everybody } & & & & \\ \text { construction/agric/mining } & 17.36 & 5.97 & 6.62 & 4.76 \\ \text { skilled manufacturing } & 13.26 & 5.96 & 3.23 & 4.07 \\ \text { semiskilled manufacturin } & 13.37 & 5.82 & 4.87 & 2.68 \\ \text { unskilled manufacturing } & 15.34 & 4.99 & 6.93 & 3.42 \\ \text { skilled professional } & 11.73 & 5.30 & 2.72 & 3.70 \\ \text { semiskilled professional } & 14.91 & 5.83 & 3.49 & 5.58 \\ \text { unskilled professional } & 13.11 & 5.37 & 4.58 & 3.15 \\ \text { skilled nonprof } & 11.28 & 4.55 & 1.96 & 4.77 \\ \text { semiskilled nonprof } & 7.75 & 3.43 & 1.14 & 3.18 \\ \text { unskilled nonprof } & 7.45 & 3.13 & 2.09 & 2.23 \\ \text { married male } & & & & \\ \text { construction/agric/mining } & 21.24 & 7.42 & 7.94 & 5.88 \\ \text { skilled manufacturing } & 16.95 & 7.10 & 4.21 & 5.64 \\ \text { semiskilled manufacturin } & 17.73 & 6.05 & 5.99 & 5.69 \\ \text { unskilled manufacturing } & 17.08 & 5.98 & 6.99 & 4.12 \\ \text { skilled professional } & 14.58 & 6.28 & 3.23 & 5.06 \\ \text { semiskilled professional } & 20.90 & 7.66 & 5.04 & 8.20 \\ \text { unskilled professional } & 15.63 & 4.98 & 6.58 & 4.08 \\ \text { skilled nonprof } & 15.24 & 5.93 & 2.68 & 6.63 \\ \text { semiskilled nonprof } & 13.10 & 5.37 & 3.05 & 4.68 \\ \text { unskilled nonprof } & 14.88 & 5.69 & 4.03 & 5.17\end{array}$

\section{married female}

construction/agric/mining skilled manufacturing semiskilled manufacturin unskilled manufacturing skilled professional semiskilled profession unskilled professional skilled nonprof semiskilled nonprof

single male

single male
construction/agric/mining semiskilled manufacturin unskilled manufacturing skilled professional

semiskilled professional unskilled profession

skilled nonprof

semiskilled nonprof
unskilled nonprof

single female

construction/agric/mining skilled manufacturing

unskilled manufact skilled professional semiskilled professional unskilled profession skilled nonprof semiskilled nonprof
unskilled nonprof

$\begin{array}{llll}14.06 & 5.81 & 4.37 & 3.88 \\ 15.48 & 8.39 & 3.77 & 3.32 \\ 16.90 & 7.62 & 5.09 & 4.18 \\ 14.11 & 4.58 & 5.95 & 3.58 \\ 12.32 & 7.12 & 2.62 & 2.58 \\ 16.23 & 9.33 & 3.33 & 3.57 \\ 15.35 & 7.82 & 4.57 & 2.96 \\ 12.41 & 6.69 & 2.79 & 2.93 \\ 11.14 & 6.04 & 1.74 & 3.36 \\ 10.29 & 4.62 & 3.09 & 2.58\end{array}$

Notes: We first calculate the impact of occupation on the predicted probability of participating in the

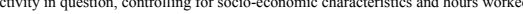
the absolute values over the 70 quarter hour periods for which we estimate our model.
Table One: Impact of Industry and Occupation on Time Allocation - weekdays and weekends Effect of occupation on probability of particiapting in non-work activities, averaged over all quarter-hour periods

Occupation

\begin{tabular}{lcccc}
\multicolumn{1}{c}{$\begin{array}{c}\text { All non-work } \\
\text { activities }\end{array}$} & $\begin{array}{l}\text { Household } \\
\text { production }\end{array}$ & $\begin{array}{l}\text { Tertiary } \\
\text { activities }\end{array}$ & Leisure \\
everybody & & & & \\
construction/agric/mining & $24.8 \%$ & $8.5 \%$ & $9.5 \%$ & $6.8 \%$ \\
skilled manufacturing & $18.9 \%$ & $8.5 \%$ & $4.6 \%$ & $5.8 \%$ \\
semiskilled manufacturing & $19.1 \%$ & $8.3 \%$ & $7.0 \%$ & $3.8 \%$ \\
unskilled manufacturing & $21.9 \%$ & $7.1 \%$ & $9.9 \%$ & $4.9 \%$ \\
skilled professional & $16.8 \%$ & $7.6 \%$ & $3.9 \%$ & $5.3 \%$ \\
semiskilled professional & $21.3 \%$ & $8.3 \%$ & $5.0 \%$ & $8.0 \%$ \\
unskilled professional & $18.7 \%$ & $7.7 \%$ & $6.5 \%$ & $4.5 \%$ \\
skilled nonprof & $16.1 \%$ & $6.5 \%$ & $2.8 \%$ & $6.8 \%$ \\
semiskilled nonprof & $11.1 \%$ & $4.9 \%$ & $1.6 \%$ & $4.5 \%$
\end{tabular}

$\begin{array}{lllll}\text { semiskilled nonprof } & 11.1 \% & 4.9 \% & 1.6 \% & 4.5 \% \\ \text { unskilled nonprof } & 10.6 \% & 4.5 \% & 3.0 \% & 3.2 \%\end{array}$

married male

$\begin{array}{lllll}\text { construction/agric/mining } & 30.3 \% & 10.6 \% & 11.3 \% & 8.4 \%\end{array}$

$\begin{array}{lrrrr}\text { semiskilled manufacturing } & 24.2 \% & 10.1 \% & 6.0 \% & 8.1 \% \\ \text { s. } & 2.3 \% & 8.6 \% & 8.6 \% & 8.1 \%\end{array}$

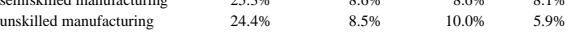

\begin{tabular}{llllr} 
skilled professional & $20.8 \%$ & $9.0 \%$ & $4.6 \%$ & $7.2 \%$ \\
\hline
\end{tabular}

$\begin{array}{lllll}\text { semiskilled professional } & 29.9 \% & 10.9 \% & 7.2 \% & 11.7 \%\end{array}$

$\begin{array}{lllll}\text { unskilled professional } & 22.3 \% & 7.1 \% & 9.4 \% & 5.8 \% \\ \text { skilled nonprof } & 21.8 \% & 8.5 \% & 3.8 \% & 9.5 \%\end{array}$

$\begin{array}{lllll}\text { semiskilled nonprof } & 21.8 \% & 8.5 \% & 3.8 \% & 9.5 \% \\ \text { unskilled nonprof } & 18.7 \% & 7.7 \% & 4.4 \% & 6.7 \% \\ & 21.3 \% & 8.1 \% & 5.8 \% & 7.4 \%\end{array}$

married female

construction/agric/mining

skilled manufacturing

semiskilled manufacturin

unskilled manufacturing

skilled professional

semiskilled profession

unskilled professiona

skilled nonprof

semiskilled nonprof
unskilled nonprof

single male

construction/agric/mining

skilled manufacturing

enskilled manufacturing

skilled professional

semiskilled profession

semiskilled profession
unskilled professional

skilled nonprof

skilled nonprof

semiskilled nonprof
unskilled nonprof

single female

construction/agric/mining skilled manufacturing semiskilled manufacturing

unskilled manufacturing

skilled professional

semiskilled professional

unskilled profession

skilled nonprof

semiskilled nonprof
unskilled nonprof

$\begin{array}{rrrr}20.1 \% & 8.3 \% & 6.2 \% & 5.5 \% \\ 22.1 \% & 12.0 \% & 5.4 \% & 4.7 \% \\ 24.1 \% & 10.9 \% & 7.3 \% & 6.0 \% \\ 20.2 \% & 6.5 \% & 8.5 \% & 5.1 \% \\ 17.6 \% & 10.2 \% & 3.7 \% & 3.7 \% \\ 23.2 \% & 13.3 \% & 4.8 \% & 5.1 \% \\ 21.9 \% & 11.2 \% & 6.5 \% & 4.2 \% \\ 17.7 \% & 9.6 \% & 4.0 \% & 4.2 \% \\ 15.9 \% & 8.6 \% & 2.5 \% & 4.8 \% \\ 14.7 \% & 6.6 \% & 4.4 \% & 3.7 \%\end{array}$

$25.6 \%-5.8 \%-11.1 \%-8.7 \%$

\begin{tabular}{rrrr}
$19.5 \%$ & $6.3 \%$ & $5.6 \%$ & $7.6 \%$ \\
\hline
\end{tabular}

\begin{tabular}{rrrr}
$20.4 \%$ & $7.0 \%$ & $7.2 \%$ & $6.2 \%$ \\
$24.9 \%$ & $4.6 \%$ & $14.5 \%$ & $5.8 \%$ \\
\hline & $4.7 \%$ & $5.5 \%$ & $8.9 \%$
\end{tabular}

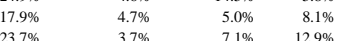

$\begin{array}{lll}23.7 \% & 3.7 \% \\ 18.1 \% & 4.5 \%\end{array}$

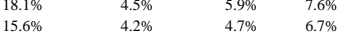

$\begin{array}{llll}15.6 \% & 4.2 \% & 4.7 \% & 6.7 \% \\ 13.5 \% & 2.7 \% & 3.4 \% & 7.5 \% \\ 12.0 \% & 2.7 \% & 4.6 \% & 4.7 \%\end{array}$

$\begin{array}{rrrr}24.2 \% & 7.5 \% & 9.1 \% & 7.6 \% \\ 21.8 \% & 7.3 \% & 6.3 \% & 8.3 \% \\ 26.7 \% & 10.7 \% & 8.0 \% & 8.1 \% \\ 27.1 \% & 7.1 \% & 12.5 \% & 7.5 \% \\ 17.5 \% & 7.0 \% & 4.1 \% & 6.3 \% \\ 21.9 \% & 5.9 \% & 6.5 \% & 9.6 \% \\ 19.7 \% & 7.0 \% & 6.6 \% & 6.2 \% \\ 15.0 \% & 4.2 \% & 2.5 \% & 8.3 \% \\ 10.6 \% & 2.9 \% & 2.6 \% & 5.2 \% \\ 9.0 \% & 3.1 \% & 2.6 \% & 3.3 \%\end{array}$

Notes: We first calculate the impact of occupation on the predicted probability of participating in the activity in question, controlling for socio-economic characteristics and hours worked. We then sum . 
Table Two: Impact of Industry and Occupation on Time Allocation - weekdays and weekends

\begin{tabular}{|c|c|c|c|c|}
\hline \multirow[t]{2}{*}{ Occupation } & \multicolumn{4}{|c|}{ activities, averaged over all quarter-hour periods } \\
\hline & $\begin{array}{c}\text { All non-work } \\
\text { activities }\end{array}$ & $\begin{array}{l}\text { Household } \\
\text { production }\end{array}$ & $\begin{array}{c}\text { Tertiary } \\
\text { activities }\end{array}$ & Leisure \\
\hline \multicolumn{5}{|l|}{ everybody - weekdays } \\
\hline construction/agric/mining & 19.66 & 6.93 & 6.92 & 5.82 \\
\hline skilled manufacturing & 16.75 & 7.35 & 3.55 & 5.85 \\
\hline semiskilled manufacturing & 15.81 & 6.96 & 4.84 & 4.00 \\
\hline unskilled manufacturing & 16.01 & 5.67 & 6.62 & 3.72 \\
\hline skilled professional & 14.81 & 6.64 & 2.75 & 5.41 \\
\hline semiskilled professional & 16.63 & 6.90 & 3.27 & 6.46 \\
\hline unskilled professional & 13.22 & 5.74 & 4.04 & 3.44 \\
\hline skilled nonprof & 13.59 & 5.71 & 2.22 & 5.66 \\
\hline semiskilled nonprof & 9.40 & 4.32 & 1.14 & 3.94 \\
\hline unskilled nonprof & 8.80 & 3.68 & 2.15 & 2.96 \\
\hline \multicolumn{5}{|l|}{ everybody - weekdays 9:5 } \\
\hline construction/agric/mining & 7.90 & 3.68 & 1.56 & 2.66 \\
\hline skilled manufacturing & 7.38 & 3.44 & 1.25 & 2.69 \\
\hline semiskilled manufacturing & 6.04 & 3.23 & 1.18 & 1.64 \\
\hline unskilled manufacturing & 6.24 & 2.89 & 1.84 & 1.51 \\
\hline skilled professional & 7.06 & 3.24 & 1.10 & 2.72 \\
\hline semiskilled professional & 8.00 & 3.52 & 1.51 & 2.97 \\
\hline unskilled professional & 5.27 & 2.72 & 0.88 & 1.67 \\
\hline skilled nonprof & 6.66 & 2.67 & 1.20 & 2.79 \\
\hline semiskilled nonprof & 4.62 & 2.12 & 0.48 & 2.02 \\
\hline unskilled nonprof & 4.06 & 1.96 & 0.52 & 1.58 \\
\hline \multicolumn{5}{|l|}{ everybody - weekends } \\
\hline construction/agric/mining & 8.77 & 2.70 & 3.59 & 2.48 \\
\hline skilled manufacturing & 7.52 & 3.06 & 2.08 & 2.38 \\
\hline semiskilled manufacturing & 9.30 & 2.59 & 2.80 & 3.91 \\
\hline unskilled manufacturing & 12.15 & 3.17 & 5.75 & 3.24 \\
\hline skilled professional & 6.07 & 1.95 & 2.02 & 2.09 \\
\hline semiskilled professional & 9.32 & 2.71 & 2.42 & 4.19 \\
\hline unskilled professional & 10.02 & 3.40 & 4.15 & 2.46 \\
\hline skilled nonprof & 6.59 & 2.32 & 1.79 & 2.48 \\
\hline semiskilled nonprof & 5.10 & 1.70 & 1.47 & 1.94 \\
\hline unskilled nonprof & 5.97 & 2.46 & 1.54 & 1.97 \\
\hline
\end{tabular}

Notes: See table One. Results for weekdays $9-5$ are summed over 32 quarters.
Table Two: Impact of Industry and Occupation on Time Allocation - weekdays and weekends

\begin{tabular}{|c|c|c|c|c|}
\hline \multirow[t]{2}{*}{ Occupation } & \multicolumn{4}{|c|}{ intarter } \\
\hline & $\begin{array}{l}\text { All non-work } \\
\text { activities }\end{array}$ & $\begin{array}{l}\text { Household } \\
\text { production }\end{array}$ & $\begin{array}{l}\text { Tertiary } \\
\text { activities }\end{array}$ & Leisure \\
\hline \multicolumn{5}{|l|}{ everybody - weekdays } \\
\hline construction/agric/mining & $28.1 \%$ & $9.9 \%$ & $9.9 \%$ & $8.3 \%$ \\
\hline skilled manufacturing & $23.9 \%$ & $10.5 \%$ & $5.1 \%$ & $8.4 \%$ \\
\hline semiskilled manufacturing & $22.6 \%$ & $9.9 \%$ & $6.9 \%$ & $5.7 \%$ \\
\hline unskilled manufacturing & $22.9 \%$ & $8.1 \%$ & $9.5 \%$ & $5.3 \%$ \\
\hline skilled professional & $21.2 \%$ & $9.5 \%$ & $3.9 \%$ & $7.7 \%$ \\
\hline semiskilled professional & $23.8 \%$ & $9.9 \%$ & $4.7 \%$ & $9.2 \%$ \\
\hline unskilled professional & $18.9 \%$ & $8.2 \%$ & $5.8 \%$ & $4.9 \%$ \\
\hline skilled nonprof & $19.4 \%$ & $8.2 \%$ & $3.2 \%$ & $8.1 \%$ \\
\hline semiskilled nonprof & $13.4 \%$ & $6.2 \%$ & $1.6 \%$ & $5.6 \%$ \\
\hline unskilled nonprof & $12.6 \%$ & $5.3 \%$ & $3.1 \%$ & $4.2 \%$ \\
\hline \multicolumn{5}{|l|}{ everybody - weekdays 9:5 } \\
\hline construction/agric/mining & $24.7 \%$ & $11.5 \%$ & $4.9 \%$ & $8.3 \%$ \\
\hline skilled manufacturing & $23.1 \%$ & $10.8 \%$ & $3.9 \%$ & $8.4 \%$ \\
\hline semiskilled manufacturing & $18.9 \%$ & $10.1 \%$ & $3.7 \%$ & $5.1 \%$ \\
\hline unskilled manufacturing & $19.5 \%$ & $9.0 \%$ & $5.7 \%$ & $4.7 \%$ \\
\hline skilled professional & $22.1 \%$ & $10.1 \%$ & $3.4 \%$ & $8.5 \%$ \\
\hline semiskilled professional & $25.0 \%$ & $11.0 \%$ & $4.7 \%$ & $9.3 \%$ \\
\hline unskilled professional & $16.5 \%$ & $8.5 \%$ & $2.7 \%$ & $5.2 \%$ \\
\hline skilled nonprof & $20.8 \%$ & $8.3 \%$ & $3.8 \%$ & $8.7 \%$ \\
\hline semiskilled nonprof & $14.4 \%$ & $6.6 \%$ & $1.5 \%$ & $6.3 \%$ \\
\hline unskilled nonprof & $12.7 \%$ & $6.1 \%$ & $1.6 \%$ & $4.9 \%$ \\
\hline \multicolumn{5}{|l|}{ everybody - weekends } \\
\hline construction/agric/mining & $12.5 \%$ & $3.9 \%$ & $5.1 \%$ & $3.5 \%$ \\
\hline skilled manufacturing & $10.7 \%$ & $4.4 \%$ & $3.0 \%$ & $3.4 \%$ \\
\hline semiskilled manufacturing & $13.3 \%$ & $3.7 \%$ & $4.0 \%$ & $5.6 \%$ \\
\hline unskilled manufacturing & $17.4 \%$ & $4.5 \%$ & $8.2 \%$ & $4.6 \%$ \\
\hline skilled professional & $8.7 \%$ & $2.8 \%$ & $2.9 \%$ & $3.0 \%$ \\
\hline semiskilled professional & $13.3 \%$ & $3.9 \%$ & $3.5 \%$ & $6.0 \%$ \\
\hline unskilled professional & $14.3 \%$ & $4.9 \%$ & $5.9 \%$ & $3.5 \%$ \\
\hline skilled nonprof & $9.4 \%$ & $3.3 \%$ & $2.6 \%$ & $3.5 \%$ \\
\hline semiskilled nonprof & $7.3 \%$ & $2.4 \%$ & $2.1 \%$ & $2.8 \%$ \\
\hline unskilled nonprof & $8.5 \%$ & $3.5 \%$ & $2.2 \%$ & $2.8 \%$ \\
\hline
\end{tabular}

Notes: See table One. Results for weekdays 9-5 are averaged over 32 quarters. 
Table 3: Impact of time use constraint on job change and retirement hazard

Time use variables

All

Hosuehold production

Tertiary activities

Leisure

Occupation variables

construction/agric/mining

$\begin{array}{ll}\text { Manufacturing } & \text { skilled } \\ & \text { semi-skilled } \\ & \text { unskilled } \\ \text { Prof services } & \text { skilled } \\ & \text { semi-skilled } \\ & \text { unskilled } \\ \text { Non-prof services } & \text { skilled } \\ & \text { semi-skilled }\end{array}$

unskilled

Socio-Economic Variables

Male

Married

Black

Education

Less than high school

Some college

Self-reported health Excellent

Very good

Fair

Poor

Plant size

less than 5 employees

5-14

$15-24$

25-99

100-499

Union member

Has pay and promotion responsibility

Self reported pension Defined contribution

type

Defined benefit Both

Job provides health insurance

At or over defined benefit pension ful retirement age

Years tenure in current job

Hourly wage

Financial wealth 81th-100th percentile 61th-80th percentile 21st-40th percentile 1st-20th percentile

Homeowner

Job requires
No time use constraints

Change job Retire

rrr

3.2

Total time use constraints

robust s.e. $\mathrm{rrr} \quad$ robust s.e. $\mathrm{rr}$
Change job Retire

robust s.e. rrr robust s.e. rrr $\begin{array}{llll}1.204 & 0.087 & 0.966 & 0.059\end{array}$
Three time use constraints

Change job Retire

robust s.e. rrr robust s.e.

$\begin{array}{lll} & \text { 61th-80th percentile } & 1.010 \\ & \text { 21st-40th percentile } & 1.023 \\ \text { Homeowner } & \text { 1st-20th percentile } & 0.901 \\ \text { Job requires } & & 0.926 \\ & \text { lots of physical effort } & 1.034 \\ & \text { lifting heavy loads } & 0.980 \\ & \text { stooping, kneeling, or crouchi } & 1.024 \\ & \text { good eyesight } & 0.944\end{array}$

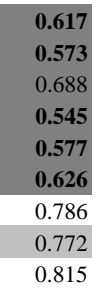

$\begin{array}{ll}0.113 & 0.936 \\ 0.108 & 1.251 \\ 0.101 & 1.073 \\ 0.084 & \mathbf{0 . 6 9 8} \\ 0.105 & 0.764 \\ 0.097 & 0.773 \\ 0.124 & 1.008 \\ 0.109 & 0.878 \\ 0.112 & 0.898\end{array}$

$\begin{array}{ll}0.154 & 1.319 \\ 0.188 & 1.199 \\ 0.133 & \\ 0.095 & 1.548 \\ 0.114 & 0.909 \\ 0.106 & 1.378 \\ 0.153 & 2.429 \\ 0.117 & 4.589 \\ 0.113 & 5.124\end{array}$

$\begin{array}{ll}0.349 & 0.811\end{array}$

$0.317 \quad 1.088$

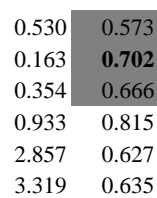

$0.171 \quad 0.703$

$0.205 \quad 1.275$

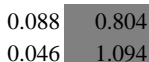

$0.046 \quad 1.094$

0.804

0.950

1.563

Job involves lots of stress

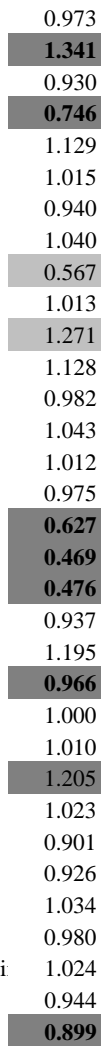

\begin{tabular}{lllll|}
\hline 0.074 & 1.099 & 0.070 & $\mathbf{1 . 3 4 1}$ \\
\hline 0.095 & $\mathbf{0 . 8 1 8}$ & 0.051 & 0.973 \\
0.084 & 1.061 & 0.077 & 0.930 \\
\hline 0.067 & 1.131 & 0.083 & $\mathbf{0 . 7 4 6}$ \\
\hline 0.085 & 0.969 & 0.062 & 1.129 \\
0.088 & $\mathbf{0 . 7 0 6}$ & 0.056 & 1.015 \\
0.069 & 0.908 & 0.056 & 0.940 \\
0.103 & $\mathbf{1 . 5 2 5}$ & 0.119 & 1.040 \\
\hline 0.173 & $\mathbf{2 . 1 3 8}$ & 0.358 & 0.567 \\
\hline 0.220 & 1.090 & 0.202 & 1.013 \\
\hline 0.159 & 0.977 & 0.119 & 1.271 \\
\hline 0.142 & 1.101 & 0.123 & 1.128 \\
0.077 & 0.959 & 0.064 & 0.982 \\
0.074 & 1.003 & 0.062 & 1.043 \\
0.022 & 1.008 & 0.016 & 1.012 \\
0.020 & $\mathbf{1 . 0 6 9}$ & 0.021 & 0.975 \\
\hline 0.049 & $\mathbf{0 . 6 2 6}$ & 0.048 & $\mathbf{0 . 6 2 7}$ \\
0.045 & 1.022 & 0.077 & $\mathbf{0 . 4 6 9}$ \\
0.053 & 1.193 & 0.097 & $\mathbf{0 . 4 7 6}$ \\
\hline 0.055 & 1.059 & 0.054 & 0.937 \\
0.253 & 1.212 & 0.152 & 1.195 \\
\hline 0.004 & 1.006 & 0.003 & $\mathbf{0 . 9 6 6}$ \\
\hline 0.000 & 0.998 & 0.002 & 1.000 \\
\hline 0.090 & 0.820 & 0.066 & 1.010 \\
\hline 0.106 & 0.837 & 0.067 & 1.205 \\
\hline 0.092 & 1.142 & 0.084 & 1.023 \\
0.092 & 1.198 & 0.095 & 0.901 \\
0.076 & 0.991 & 0.077 & 0.926 \\
0.039 & 0.974 & 0.030 & 1.034 \\
0.044 & 0.969 & 0.037 & 0.980 \\
0.039 & 1.002 & 0.033 & 1.024 \\
0.037 & 0.999 & 0.033 & 0.944 \\
0.034 & 0.941 & 0.031 & $\mathbf{0 . 8 9 9}$ \\
\hline & & & \\
\hline
\end{tabular}

$\begin{array}{lll}0.095 & \mathbf{0 . 8 1 8}\end{array}$

$\begin{array}{ll}0.074 & 1.099\end{array}$

$0.084 \quad 1.061$

\begin{tabular}{|l|l|}
0.067 & 1.131 \\
\hline
\end{tabular}

$0.085 \quad 0.969$

\begin{tabular}{|l|l|}
0.088 & $\mathbf{0 . 7 0 6}$ \\
\hline
\end{tabular}

$0.069 \quad 0.908$

$0.103 \quad 1.525$

$\begin{array}{ll}0.173 & 2.138\end{array}$

$0.220 \quad 1.090$

$0.159 \quad 0.977$

$0.142 \quad 1.101$

$0.077 \quad 0.959$

$0.074 \quad 1.003$

$0.022 \quad 1.008$

$\begin{array}{ll}0.020 & \mathbf{1 . 0 6 9}\end{array}$

$\begin{array}{ll}0.049 & \mathbf{0 . 6 2 6}\end{array}$

$0.045 \quad 1.022$

\begin{tabular}{ll}
0.053 & 1.193 \\
\hline
\end{tabular}

$0.055 \quad 1.059$

$0.253 \quad 1.212$

$0.004 \quad 1.006$

$0.000 \quad 0.998$

$0.090 \quad 0.820$

$\begin{array}{ll}0.106 & 0.837\end{array}$

$0.092 \quad 1.142$

$0.092 \quad 1.198$

$0.076 \quad 0.991$

$0.039 \quad 0.974$

$0.044 \quad 0.969$

$0.039 \quad 1.002$

$0.037 \quad 0.999$

$0.034 \quad 0.941$

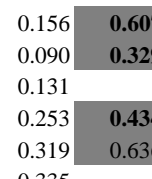

0.335

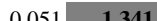

$\begin{array}{ll}0.051 & 1.341 \\ 0.070 & 0.973\end{array}$

$0.077 \quad 0.930$

$\begin{array}{ll}0.083 & \mathbf{0 . 7 4 6}\end{array}$

$0.062 \quad 1.129$

$0.056 \quad 1.015$

$0.056 \quad 0.940$

$0.119 \quad 1.040$
0.358

$0.358 \quad 0.567$

\begin{tabular}{ll}
$0.202 \quad 1.013$ \\
\hline
\end{tabular}

\begin{tabular}{|l|l|}
0.119 & 1.271 \\
\hline
\end{tabular}

$\begin{array}{ll}0.123 & 1.128\end{array}$

$0.064 \quad 0.982$

$0.062 \quad 1.043$

$0.016 \quad 1.012$

$0.021 \quad 0.975$

0.048
0.627

$0.077 \quad \mathbf{0 . 4 6 9}$

$0.097 \quad 0.476$

$0.054 \quad 0.937$

$0.152 \quad 1.195$

$\begin{array}{lll}0.003 & \mathbf{0 . 9 6 6}\end{array}$

$0.002 \quad 1.000$

$0.066 \quad 1.010$

$0.067 \quad 1.205$

$0.084 \quad 1.023$

$0.095 \quad 0.901$

$0.077 \quad 0.926$

$0.030 \quad 1.034$

$0.037 \quad 0.980$

$0.033 \quad 1.02$

$0.033 \quad 0.944$

$\begin{array}{ll}0.031 & \mathbf{0 . 8 9 9}\end{array}$ $\begin{array}{lll}0.166 & 1.381 & 1.381\end{array}$

$\begin{array}{lll}0.305 & \mathbf{1 . 8 4 5} & 1.845\end{array}$

$\begin{array}{lll}0.115 & 0.980 & 0.980\end{array}$

$\begin{array}{lll}0.110 & 0.884 & 0.884\end{array}$

$\begin{array}{lll}0.134 & 1.119 & 1.119\end{array}$

$\begin{array}{lll}0.120 & 1.008 & 1.008\end{array}$

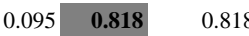

$\begin{array}{lll}0.074 & 1.099 & 1.099\end{array}$

$\begin{array}{lll}0.084 & 1.061 & 1.061\end{array}$

$\begin{array}{llll}0.067 & 1.131 & 1.131\end{array}$

$\begin{array}{lll}0.085 & 0.969 & 0.969\end{array}$

\begin{tabular}{|l|l|l|}
0.088 & $\mathbf{0 . 7 0 6}$ & 0.706
\end{tabular}

$\begin{array}{lll}0.069 & 0.908 & 0.908\end{array}$

\begin{tabular}{|l|l|l|}
\hline 0.103 & 1.525 & 1.525 \\
\hline
\end{tabular}

$\begin{array}{llll}0.173 & 2.138 & 2.138\end{array}$

$\begin{array}{lll}0.220 & 1.090 & 1.090\end{array}$

$\begin{array}{lll}0.159 & 0.977 & 0.977\end{array}$

$0.142 \quad 1.101 \quad 1.101$

$\begin{array}{lll}0.077 & 0.959 & 0.959\end{array}$

$\begin{array}{lll}0.074 & 1.003 & 1.003\end{array}$

$\begin{array}{lll}0.022 & 1.008 & 1.008\end{array}$

\begin{tabular}{ll|l|l}
0.020 & $\mathbf{1 . 0 6 9}$ & 1.069
\end{tabular}

\begin{tabular}{llll}
0.049 & $\mathbf{0 . 6 2 6}$ & 0.626 \\
\hline
\end{tabular}

$\begin{array}{lll}0.045 & 1.022 & 1.022\end{array}$

$\begin{array}{llll}0.053 & 1.193 & 1.193\end{array}$

$\begin{array}{lll}0.055 & 1.059 & 1.059\end{array}$

$\begin{array}{lll}0.253 & 1.212 & 1.212\end{array}$

$\begin{array}{lll}0.004 & 1.006 & 1.006\end{array}$

$\begin{array}{lll}0.000 & 0.998 & 0.998\end{array}$

$0.090 \quad 0.820-0.820$

$\begin{array}{llll}0.106 & 0.837 & 0.837\end{array}$

$\begin{array}{lll}0.092 & 1.142 & 1.142\end{array}$

$\begin{array}{llll}0.092 & 1.198 & 1.198\end{array}$

$\begin{array}{lll}0.076 & 0.991 & 0.991\end{array}$

$\begin{array}{lll}0.039 & 0.974 & 0.974\end{array}$

$\begin{array}{lll}0.044 & 0.969 & 0.969\end{array}$

$\begin{array}{lll}0.039 & 1.002 & 1.002\end{array}$

$\begin{array}{lll}0.037 & 0.999 & 0.999\end{array}$

$\begin{array}{llll}0.034 & 0.941 & 0.941\end{array}$

Notes: The above table reports the efefcts of the covariates on the likelihood of changing job or retiring relative to a base case of staying in the existing job. If the relative risk ratio is less than one, the covariate reduces the likelihood of the transition, and conversely, if the value is greater than one, it increases the liklihood. Dark shading and bolded text indicates $1 \%$ statistical significance; dark shading indicates $5 \%$ significance, light shading indicates $10 \%$ significance. 
Table 4: Impact of time use constraint on job change and retirement hazard - additional specifications

Time use variables

Hosuehold production

Tertiary activities

Leisure

Occupation variables

$\begin{array}{ll}\text { Manufacturing } & \text { skilled } \\ \text { semi-skilled } \\ \text { Prof services } & \text { skilled } \\ \text { semi-skilled } \\ \text { Non-prof services } & \text { skilled } \\ & \text { semi-skilled }\end{array}$

Time use variables

Hosuehold production

Tertiary activities

Leisure

Occupation variables

$\begin{array}{ll}\text { Manufacturing } & \text { skilled } \\ \text { semi-skilled } \\ \text { Prof services } & \text { skilled } \\ \text { semi-skilled } \\ \text { Non-prof services } & \begin{array}{l}\text { skilled } \\ \text { semi-skilled }\end{array}\end{array}$

\section{Weekdays}

Change job

rrr robust s.e. rrr robust s.e. rrr robust s.e. rrr robust s.e.

0.824
0.99
$\mathbf{1 . 3 4}$

0.998

\begin{tabular}{ll}
0.086 & 0.825 \\
0.052 & $\mathbf{1 . 1 2 1}$ \\
\hline
\end{tabular}

$0.120 \quad 1.067$

\begin{tabular}{ll}
0.146 & 0.682 \\
0.239 & $\mathbf{1 . 4 8 7}$ \\
\hline 0.434 & 1.358 \\
\hline
\end{tabular}

$0.043 \quad 1.325$

$0.082 \quad 1.943$

$0.434 \quad 1.358$

\begin{tabular}{|c|c|c|c|c|c|c|c|c|c|c|c|}
\hline 0.658 & 0.187 & 1.490 & 0.353 & 0.580 & 0.110 & 0.966 & 0.163 & 2.001 & 0.893 & 1.179 & 0.474 \\
\hline 0.981 & 0.216 & 1.799 & 0.303 & 1.160 & 0.281 & 1.807 & 0.335 & 6.581 & 8.115 & 0.919 & 0.995 \\
\hline 0.575 & 0.143 & 1.094 & 0.218 & 0.465 & 0.083 & 0.695 & 0.107 & 0.331 & 0.093 & 0.605 & 0.153 \\
\hline 0.471 & 0.138 & 1.107 & 0.260 & 0.414 & 0.101 & 0.648 & 0.133 & 14.629 & 23.456 & 0.566 & 0.806 \\
\hline 0.646 & 0.160 & 1.381 & 0.293 & 0.430 & 0.139 & 0.708 & 0.196 & 1.470 & 0.493 & 0.943 & 0.275 \\
\hline 0.801 & 0.132 & 1.167 & 0.161 & 0.736 & 0.111 & 0.913 & 0.122 & 0.384 & 0.127 & 0.729 & 0.223 \\
\hline
\end{tabular}

\begin{tabular}{|c|c|c|c|c|c|c|c|c|c|c|c|}
\hline 0.658 & 0.187 & 1.490 & 0.353 & 0.580 & 0.110 & 0.966 & 0.163 & 2.001 & 0.893 & 1.179 & 0.474 \\
\hline 0.981 & 0.216 & 1.799 & 0.303 & 1.160 & 0.281 & 1.807 & 0.335 & 6.581 & 8.115 & 0.919 & 0.995 \\
\hline 0.575 & 0.143 & 1.094 & 0.218 & 0.465 & 0.083 & 0.695 & 0.107 & 0.331 & 0.093 & 0.605 & 0.153 \\
\hline 0.471 & 0.138 & 1.107 & 0.260 & 0.414 & 0.101 & 0.648 & 0.133 & 14.629 & 23.456 & 0.566 & 0.806 \\
\hline 0.646 & 0.160 & 1.381 & 0.293 & 0.430 & 0.139 & 0.708 & 0.196 & 1.470 & 0.493 & 0.943 & 0.275 \\
\hline 0.801 & 0.132 & 1.167 & 0.161 & 0.736 & 0.111 & 0.913 & 0.122 & 0.384 & 0.127 & 0.729 & 0.223 \\
\hline
\end{tabular}

\begin{tabular}{rr|}
\hline 0.163 & 2.001 \\
0.335 & 6.581 \\
0.107 & $\mathbf{0 . 3 3 1}$ \\
0.133 & 14.629 \\
\hline 0.196 & 1.470 \\
\hline 0.122 & $\mathbf{0 . 3 8 4}$
\end{tabular}

\begin{tabular}{|c|c|c|c|c|c|c|c|c|c|c|c|}
\hline 0.658 & 0.187 & 1.490 & 0.353 & 0.580 & 0.110 & 0.966 & 0.163 & 2.001 & 0.893 & 1.179 & 0.474 \\
\hline 0.981 & 0.216 & 1.799 & 0.303 & 1.160 & 0.281 & 1.807 & 0.335 & 6.581 & 8.115 & 0.919 & 0.995 \\
\hline 0.575 & 0.143 & 1.094 & 0.218 & 0.465 & 0.083 & 0.695 & 0.107 & 0.331 & 0.093 & 0.605 & 0.153 \\
\hline 0.471 & 0.138 & 1.107 & 0.260 & 0.414 & 0.101 & 0.648 & 0.133 & 14.629 & 23.456 & 0.566 & 0.806 \\
\hline 0.646 & 0.160 & 1.381 & 0.293 & 0.430 & 0.139 & 0.708 & 0.196 & 1.470 & 0.493 & 0.943 & 0.275 \\
\hline 0.801 & 0.132 & 1.167 & 0.161 & 0.736 & 0.111 & 0.913 & 0.122 & 0.384 & 0.127 & 0.729 & 0.223 \\
\hline
\end{tabular}

4.5

4.6

Married male - weekdays and weekends Married female - weekdays and weekends $\quad$ Single - weekdays and weekends

Weekends

$0.209 \quad 1.817$

$\begin{array}{lll}0.181 & 1.234 & 0.863\end{array}$

\begin{tabular}{|c|c|c|c|c|c|c|c|c|c|c|c|}
\hline 0.797 & 0.197 & 0.969 & 0.191 & 0.858 & 0.060 & 0.907 & 0.050 & 1.002 & 0.151 & 0.803 & 0.098 \\
\hline 1.081 & 0.093 & 1.059 & 0.077 & 1.142 & 0.230 & 1.087 & 0.145 & 1.105 & 0.055 & 1.182 & 0.045 \\
\hline 1.674 & 0.375 & 1.117 & 0.193 & 0.813 & 0.416 & 0.918 & 0.293 & 0.780 & 0.111 & 0.941 & 0.101 \\
\hline 0.710 & 0.243 & 0.983 & 0.277 & 1.845 & 1.040 & 1.900 & 0.783 & 1.587 & 0.614 & 1.666 & 0.579 \\
\hline 0.512 & 0.146 & 1.292 & 0.299 & 1.288 & 0.765 & 1.565 & 0.573 & 1.024 & 0.489 & 2.691 & 1.045 \\
\hline 0.798 & 0.260 & 0.783 & 0.211 & 1.328 & 0.404 & 1.071 & 0.244 & 1.050 & 0.298 & 1.413 & 0.335 \\
\hline 0.382 & 0.197 & 0.657 & 0.356 & 2.260 & 1.442 & 1.459 & 0.595 & 1.056 & 0.495 & 1.023 & 0.380 \\
\hline 0.468 & 0.151 & 1.120 & 0.304 & 1.750 & 0.635 & 1.482 & 0.421 & 2.609 & 1.193 & 1.432 & 0.540 \\
\hline 1.418 & 0.316 & 1.067 & 0.237 & 1.628 & 1.140 & 1.270 & 0.573 & 1.317 & 0.373 & 1.144 & 0.288 \\
\hline
\end{tabular}




\section{RECENT WORKING PAPERS FROM THE \\ CENTER FOR RETIREMENT RESEARCH AT BOSTON COLLEGE}

Dual-Eligible Medicaid Spending: Are We on the Flat of the Curve?

Melissa A. Boyle, Joanna N. Lahey, and Margaret E. Czervionke, November 2008

Public Long-Term Care Insurance and the Housing and Living Arrangements of the Elderly: Evidence from Medicare Home Health Benefits

Gary V. Engelhardt and Nadia Greenhalgh-Stanley, November 2008

The Impact of Changing Earnings Volatility on Retirement Wealth

Austin Nichols and Melissa M. Favreault, November 2008

The Housing Bubble and Retirement Security

Alicia H. Munnell and Mauricio Soto, with the assistance of Jean-Pierre Aubry, November 2008

How Much Do State and Economic and Other Characteristics Affect Retirement Behavior?

Alicia H. Munnell, Mauricio Soto, Robert K. Triest, and Natalia A. Zhivan, August 2008

Will People Be Healthy Enough to Work Longer?

Alicia H. Munnell, Mauricio Soto, and Alex Golub-Sass, August 2008

An Assessment of Life-Cycle Funds

Mauricio Soto, Robert K. Triest, Alex Golub-Sass, and Francesca Golub-Sass, May 2008

Participant Perceptions and Decision-Making Concerning Retirement Benefits Colleen E. Medill, February 2008

A Micro-Level Analysis of Recent Increases in Labor Participation Among Older Workers

Kevin E. Cahill, Michael D. Giandrea, and Joseph F. Quinn, February 2008

The Trajectory of Wealth in Retirement

David A. Love, Michael G. Palumbo, and Paul A. Smith, February 2008

The Rising Age at Retirement in Industrial Countries

Gary Burtless, February 2008

All working papers are available on the Center for Retirement Research website

(http://www.bc.edu/crr) and can be requested by e-mail (crr@bc.edu) or phone (617-552-1762). 